\title{
Individual Characteristics and Social Learning Modelling Factors Influencing ICT Skills Development among Postgraduate Students at the University of Ibadan, Ibadan, Nigeria
}

\author{
Ogunsola, K. \& Adesakin, M.A. \\ Africa Regional Centre for Information Science \\ University of Ibadan \\ Ibadan, Nigeria \\ E-mails: olukemi11@yahoo.com,waleadesakin@gmail.com \\ Phones: +234-8068125011, +234-8168437192
}

\begin{abstract}
Information communication technologies (ICT) offer opportunities to young people through guided education and skill acquisition, which in turn lead to youth's self-sustainability, and employment. Despite the immense contributions and benefits of ICT to economic development and reduction of unemployment, there is a little overarching investigation regarding the factors affecting ICT skills development among students in the University of Ibadan. This study investigates how individual characteristics and social learning modelling factors influence ICT skills development among postgraduate students in the University of Ibadan. The study adopted a survey research design. Data were collected from a sample of 398 postgraduate students. Frequency counts and percentages, Chi-square test, Spearman's rank correlation, and multiple linear regression were used for data analysis. Three research questions were answered and three hypotheses were tested at 0.05 level of significance. The result showed that individual characteristics and social learning modelling factors jointly influenced the ICT skills development of postgraduate students $\left(F_{(9,388)}=9.488, P<0.05\right)$. The study showed that students recognise that ICT skills are required to succeed in today's world and are deemed necessary for employment. The respondents expressed interest in developing ICT skills to boost their employability. They also felt that the university management is obligated to provide training on ICT skills. Based on this, the study recommends that educational institutions and the government should implement effective policies for students to acquire sufficient ICT skills. The study also recommends that ICT skills development programmes should be incorporated into academic programmes of universities in Nigeria.
\end{abstract}

Keywords: Information and Communication Technology, Digital Literacy, ICT Complementary Skills, Nigeria, Postgraduate Students, Ibadan, University.

Journal Reference Format:

Ogunsola, K. \& Adesakin, M.A. (2020): Individual Characteristics and Social Learning Modelling Factors Influencing ICT Skills Development among Postgraduate Students at the University of Ibadan, Ibadan, Nigeria. Social Informatics, Business, Politics, L:aw \& Technology Journal. Vol. 6 . No. 2, Pp 13-30. www.isteams/socialinformaticsjournal

\section{BACKGROUND TO THE STUDY}

The seeming skills mismatch between Nigeria's tertiary institutions and the labour market has not done much to salvage the present dire economic situation in the country. This is evident in the high growth rate of unemployed persons in Nigeria. 
An unemployed person is someone that is currently available for work and actively seeking work but cannot find one. This includes unemployed youths who are economically inactive and currently not in any form of education, employment or training (Eurostat, 2020). The National Bureau of Statistics (NBS) puts the figure of unemployed youths at 19.70 percent of the population (Agbodike, Igbokwe and Umeifekem, 2015). According to Statista (2020), the figure was $13.96 \%$ in 2019, suggesting about 30 million unemployed youths in Nigeria. Having this large percentage of unemployed youths will adversely affect the development of any economy. In the present digital era, digital literacy improves the chances of being employed as it empowers individuals to participate in society's economic and cultural activities via ICT (De-Hoyos, Green, Barnes, Behle, Baldauf, and Owen, 2012). ICT skills have been referred to as the 'gateway skills' without which a person's likelihood of finding employment would be greatly reduced (De-Hoyos et al., 2012), especially as notifications by many employers come via the Internet and web-based services.

Information communication technologies include any communication devices or applications such as radio, television, mobile phones, computer network, satellite systems as well as other services and applications associated with them, such as video conferencing and distance learning tools (Ogunsola and Alade, 2016; SearchCIO, 2016). Furthermore, there is a wide range of skills, from the most basic to very advanced, which offers opportunities for people to use ICT to bring about self-sustainability and employment. According to the International Telecommunication Union (2014), there is a wide range of ways that ICT are revolutionising all sectors of the economy and creating new avenues for starting a business. The popularisation of Web 2.0, social media, mobile apps, and other ICT advancements have dramatically changed the ways things were done.

This study focuses on factors affecting ICT skills development among postgraduate students in the University of Ibadan. These are individual characteristics and social learning modelling factors. Individual characteristics refer to age, educational level, course of study, and ICT competence level within the population. Social learning modelling factors pertain to social learning theory which deals with the ability of learners to imbibe and show the behaviours exhibited within their environment. Bandura (1977), as cited in McLeod (2016), believed that behaviour is learned from the environment through the process of observational learning. Social learning modelling factors include attention, retention, reproduction, and motivation. Attention is about the learner's characteristics such as sensory capacities, arousal level, perceptual set and past reinforcement towards ICT skills. Retention is about the way learners retain ICT skills through a cognitive organisation, and motor imagery. Reproduction is about learners been able to easily reproduce the learnt ICT skills. Motivation relates to the effects of past achievements and promised incentives for successfully learning ICT tasks. This study is therefore designed to determine the influence of individual characteristics as well as social learning modelling factors on ICT skills development.

For this study, ICT skills development comprised of computer literacy skills, digital literacy skills, and ICT complementary skills. Computer literacy refers to the ability to use computers and related technologies. It is generally understood as the knowledge and skills needed to effectively use the hardware and software components of a computer (European Commission, 2008). Computer literacy has become a required skill for almost every job. In the health sector, for example, hospital employees must be able to use medical records systems, order supplies, manage appointments and perform other routine tasks on a computer instead of paper. Even in many jobs that do not entail contact with a computer, employers commonly screen for basic computer skills as minimum qualification before employment. An increasing number of non-IT positions also expect people to have more advanced skills, such as basic trouble-shooting and using advanced features in productivity programmes, though IT professionals can still be relied upon for most advanced functions (International Telecommunication Union, 2014). 
In this study, computer literacy was measured by basic computer skills, intermediate skills, as well as, advanced skills. Basic computer skills include understanding operating systems, managing files and folders, using a mouse and keyboards. Intermediate skills include performing basic functions with productivity software (word processing, spreadsheet and so on), installing software and hardware, using email and web browsers and so on. Advanced skills include the ability to manage databases and fixing simple computer problems among others.

Being digitally literate refers to the ability to effectively and critically navigate, evaluate and create information using a range of digital technologies and the inclusion of such competencies as netiquette, engaging in online citizenship and protecting personal data. In this study, digital literacy skills were measured in 5 sub-sections; information, communication, content creation, safety and problem solving. ICT complementary skills focus on the ICT-related skills required for meaningful participation in society as well as work (The International Telecommunication Union, 2014). In this study, ICT complementary skills were measured by career skills, as well as learning and innovation skills.

\subsection{Statement of the Problem}

Studies show that ICT is a promising avenue to tackle the problem of unemployment (Yigitcanlar and Baum, 2009; International Telecommunication Union, 2014; and World Bank Live, 2016). Training youths to use ICT is seen as a way for youths to acquire skills as well as jobs. It helps to reach more youths with training and to provide new ways for youth and potential employers to connect. Despite the immense contributions and benefits of ICT to economic development, and reduction of unemployment in Nigeria, there is no known study targeted at investigating individual characteristics and social learning modelling factors influencing ICT skills development among postgraduate students in the University of Ibadan. This study fills the gap.

Some related studies have been conducted on ICT skills development among young people. Eze (2013) conducted a study on integrating ICT in re-branding Nigerian youths for constructive empowerment and mental reengineering. The study highlighted the impact and areas where ICT has yielded a positive change in rebranding Nigerian youths to achieve better mental capacity building. However, the study did not investigate factors affecting ICT skills development among postgraduate students in the University of Ibadan, Nigeria. Centeno, Cullen, Kluzer, and Hache (2012) conducted a study on ICT for disadvantaged youths, pointing out the opportunities and challenges. The study found that there is a divide on digital skills, access and uses among youths. It also found that ICT-based initiatives are at risk, are underdeveloped and that ICT-based initiatives enhance inclusion by supporting youth resilience factors. Mwewa, Elizabeth and Allan (2012) investigated the development of ICT skills among mathematics students at Mukuba University, Zambia and found that sex, age, nature of the province where they stay, confidence level, year of study, and the use of ICTs in a lecture affected the development of ICT skills among the undergraduate students. However, none of these studies has investigated factors affecting ICT skills development among postgraduate students in the University of Ibadan. This study, therefore, fills the knowledge gap.

Hou (2015) investigated the effect of social factors on children's foreign language learning in Taiwan. Asgarkhani and Wan (2008) compared ICT skills that students acquired throughout their course of studies with skills identified by the ICT industry as being crucial for the ICT job sector. Poelmans, Truyen, and Stockman (2012) examined ICT skills, gender effect and computer self-efficacy of higher education students at Hogeschool-Universiteit Brussel and Katholieke Universiteit Leuven, Belgium. The studies by Asgarkhani and Wan (2008) as well as that of Poelmans, Truyen, and Stockman (2012) focused on ICT skills, computer self-efficacy levels and gender but neither considered the influence of individual characteristics and social learning modelling factors on ICT skills development. 
Elsaadani (2015) studied the ICT skills' sufficiency of Egyptian accounting graduates by soliciting the opinion of senior accounting professionals in Egypt. The research revealed that fresh graduates should be literate in the Internet, word processing software, spreadsheet software, e-mail, commercial accounting software, and database management software. Hall, Nix and Baker (2013) examined student experiences and perceptions of digital literacy skills development, while Jagodic and Dermol (2015) conducted a study on ICT tools for the development of entrepreneurial competencies for young people and for those who intend to start their businesses in seven European Union countries of Italy, Netherlands, Poland, Portugal, Slovenia, Spain, United Kingdom, and Turkey. Bassey and Ushie (2013) examined the role of ICT in skilled manpower development through vocational-technical education among higher institutions in Cross River State, Nigeria. Barakabitze, Kitindi, Sanga, Kibirige and Makwinya (2015) conducted a study on exploring students' skills and attitudes on the effective use of ICT in selected Tanzanian public secondary schools. Israel and Ediseri (2014) examined the ICT skills and internet usage of undergraduates of library and information science departments of Delta and Edo states universities. These studies leave a knowledge gap relating to how ICT skills development can be influenced by individual characteristics and social learning modelling factors; this study fills the gap.

\subsection{Objectives}

The specific objectives of the study are to;

1. describe the level of ICT skills development among postgraduate students in the University of Ibadan.

2. examine the influence of individual characteristics on ICT skills development among postgraduate students in the University of Ibadan.

3. identify social learning modelling factors that affect the development of ICT skills among postgraduate students in the University of Ibadan.

4. determine the predictive effect of the independent variables (individual characteristics, and social learning modelling factors) on ICT skills development among postgraduate students in the University of Ibadan.

\subsection{Research Questions}

1. What is the level of ICT skills development among postgraduate students in the University of Ibadan?

2. What individual characteristics influence ICT skills development among postgraduate students in the University of Ibadan?

3. What social learning modelling conditions affect ICT skills development among postgraduate students in the University of Ibadan?

\subsection{Research Hypotheses}

1. There is no significant relationship between individual characteristics and ICT skills development among postgraduate students in the University of Ibadan.

2. There is no significant influence of social learning modelling factors (attention, retention, reproduction, and motivation) on ICT skills development among postgraduate students in the University of Ibadan.

3. There is no significant predictive joint effect of the independent variables (individual characteristics, and social learning modelling factors) on ICT skills development among postgraduate students in the University of Ibadan. 
These research hypotheses lead to the research model for this study (Figure 1). The hypotheses suggest that the postgraduate students' ICT skills development is influenced by (1) individual characteristics of students such as age, educational level, course of study, and ICT competence level; (2) social learning modelling factors like attention, retention, reproduction, and motivation.

\section{LITERATURE REVIEW}

\subsection{Concept of ICT}

Information and communication technology was introduced in the early 1990s (Adesote \& Fatoki, 2013). Lallana \& Margaret (2003) described ICT as a broad range of computers, communication equipment and the services associated with them. ICT are electronic technologies used for information storage and retrieval (Adomi \& Kpangbam, 2010; Ogunsola \& Adekola, 2019). They are modern technologies developed to aid the capturing, processing, storage and retrieval, and communication of information whether in the form of numerical data, text, sound or image. Gupta and Ansari (2007) view ICT as tools used in information-handling to convert, store, process, transmit and retrieve information. These include online databases, television, Automatic Teller Machine, (ATM), telex and computers. ICT covers Internet services provision, telecommunications equipment and services, media broadcasting, libraries, and documentation centres, commercial information providers, networked-based information services, and other related information and communication activities (Economic Commission for Africa (ECA) (2008). It has been noted as a global phenomenon of great value in all aspects of human endeavour, spanning levels of education, governance, business, labour, market shares, productivity, trade, agriculture and commerce (Agbetuyi \& Oluwatayo, 2012).

The term ICT is sometimes used interchangeably with IT due to the involvement of telecommunication in transporting information across two computer systems. Gupta and Ansari (2007) posit that ICT primarily hinges on four technologies, these are:

- computer hardware technologies such as computers, midsize servers, and large mainframe systems, input, output and storage devices that support them

- software like web browsers software, productivity suits, and software for business applications

- telecommunication and network technologies such as telecommunications, media processors and software needed to provide wire-based and wireless access, support for Internet and their networks

- data resource management technologies like database management systems, software for the development, access and maintenance of the databases of an organization.

\subsection{ICT skills}

The International Telecommunication Union (2014) believes that ICT skills are required to succeed in today's world and necessary for employment. The skills are computer literacy, digital literacy and ICT complementary skills. Computer literacy refers to the ability to use computers and related technologies. It is the knowledge and skills needed to effectively use hardware and software components (European Commission, 2008). Computer literacy skills are required for almost every job. In the health sector, for example, hospital employees must be able to use medical records systems, order supplies, manage appointments and perform other routine tasks on a computer. An increasing number of non-IT positions also expect people to have ICT skills, such as basic trouble-shooting and using advanced features in productivity programmes, though IT professionals can still be relied upon for most advanced functions (International Telecommunication Union, 2014). 
Digital skills refer to the ability to effectively and critically navigate, evaluate and create information using a range of digital technologies. Digital skills include competencies in netiquette, engaging in online citizenship, and protecting personal data. ICT complementary skills are the ICT-related skills required for meaningful participation in society for lifelong success (Partnership for 21st Century Skills, 2009). The quest for progress in both science and technology in many societies depend largely on the potentials of ICT (Alade and Ogunsola, 2008).

\subsection{Theoretical Framework}

Psychologists and sociologists in the field of education such as John Bowlby's (1907-1990), Albert Banduras (1925), Jean Piaget (1896-1980) and Lev Semyonovich Vygotsky's (1896-1934), argue on whether the development of skills is the result of nature or nurture (Mwewa, Elizabeth and Allan (2012). The proponents of the nurturing concept further divided into two camps: prenatal and postnatal environments. The prenatal environment is the environment the individual goes through before birth while the postnatal environment is the one the child experiences from birth to the time one dies (McLeod, 2007). Bowlby (1988) in McLeod (2007) in his theory of attachment postulated that nature plays an important role in the development of the individual. The theory of attachment proposes that individuals come into the world biologically pre-programmed to form attachments with others, as this will help them to survive. Students applying for studies at any higher learning institution have an innate need to develop ICT skills in the institution. When they report and attend the first few lectures they get attached to their lecturers with whom they may either like the use of ICT or have a phobia for ICT. This experience is not limited to the lecturers but even to students in their halls of residence. Students may think ICT skills are not necessary if the attachment to lecturers and colleagues whom they would like to learn from is not achieved.

Albert Banduras' Social Learning Theory: this theory posits that people learn from one another via observation, imitation, and modelling. It explains human behaviour in terms of continuous reciprocal interaction with cognitive, behavioural, and environmental influences. He outlined the necessary conditions for effective modelling as follows:

- Attention - this refers to a learner's sensory capacities, arousal level, and perceptual set, and past reinforcement.

- Retention - this involves remembering what one paid attention to. It may include cognitive organization, symbolic rehearsal, and motor rehearsal.

- Reproduction - this involves reproducing learnt material or activities.

- Motivation - having a good reason to imitate. It Includes motives such as past achievements, promised incentives or rewards when successful in a learning task.

This study examined how these variables and its sub-constructs such as Social Learning Modelling Factors (attention, retention, reproduction and motivation) as well as individual characteristics (age, educational level, course of study, and ICT competency level) influence the ICT skills development of postgraduate students in the University of Ibadan.

\section{METHODOLOGY}

\subsection{Research Design}

This study adopted a survey research design. The study population comprised of postgraduate students in the University of Ibadan, Nigeria. According to the 2017/2018 data from the university academic planning unit, the total number of postgraduate students stands at 15,712 from 24 faculties, centres and institutes. The study adopted a convenience sampling technique to select 400 respondents from 18 faculties, centres and institutes. The sample 
selection was based on the recommendation given by Gay and Airasian (2003) that beyond 5000, population size is almost irrelevant and a sample size of about 400 should be adequate. Data for this study were collected using a questionnaire. The questionnaire consists of three sections.

Section A captured data on demographic characteristics of the respondents such as age, course of study, level of study, and ICT competence level. Five items were used to assess the extent to which an individual feels competent in ICT skills, such as confidence in using computers, confidence in browsing websites, confidence sending emails, confidence in using social media such as Facebook, Twitter, and confidence in using mobile phones. ICT competence was rated on a three-point scale of $1=$ Not confident at all, $2=$ usually needs help, $3=$ confident. Section A also captured the ICT skills development level based on a five-point scale of 5 to 1 , with $5=$ excellent and $1=$ poor.

Section B has information on dependent or predicted ICT skills development variables. This section was sub-divided into three sections namely computer literacy skills, digital literacy, and ICT complementary skills. Computer literacy skills and digital literacy skills were adapted from the International Telecommunication Union (2014). Respondents were asked to indicate if they have a particular ICT skill or not. These were measured using binary yes or no questions. 'Yes' was coded as 1 , 'No' was coded as 0 . Section $\mathrm{C}$ centred on social learning modelling factors such as attention, retention, reproduction and motivation. The items for measuring this variable were adapted from the study of Mwewa, Elizabeth and Allan (2012). The items related to these variables were measured on a 4-point scale ranging from strongly agree $=$ as 4 , to strongly disagree $=1$.

The internal consistency for the variables in the questionnaire was determined using Cronbach Alpha which yielded 0.802 scores for individual characteristics, 0.861 for social learning modelling factors and 0.836 for ICT skills development. A total of 400 copies of questionnaire were administered to the sampled population; 398 valid copies were retrieved and considered fit for analysis. The data collected from the questionnaire were analyzed and processed using the Statistical Package for Social Sciences (SPSS), version 20. Frequency count, percentages, mean scores, the Chi-square test of association, Spearman's rank correlation and regression analysis were used for data analysis. 


\section{DATA PRESENTATION}

\subsection{Demographic Characteristics}

Table 1: Demographic Characteristics of the Respondents $(\mathrm{N}=398)$

\begin{tabular}{|c|c|c|c|}
\hline Variable & Measurement & Frequency & Percentage (\%) \\
\hline \multirow[t]{2}{*}{ Sex } & Male & 158 & 39.7 \\
\hline & Female & 240 & 60.3 \\
\hline \multirow{5}{*}{ Age } & $20-24$ years & 107 & 26.9 \\
\hline & $25-29$ years & 216 & 54.3 \\
\hline & $30-34$ years & 54 & 13.6 \\
\hline & $35-39$ years & 9 & 2.3 \\
\hline & 40 years and above & 12 & 3.0 \\
\hline \multirow{4}{*}{$\begin{array}{l}\text { Educational } \\
\text { Level }\end{array}$} & Ph.D. & 22 & 5.5 \\
\hline & M.Phil./PhD & 11 & 2.8 \\
\hline & M.Sc. & 363 & 91.2 \\
\hline & PGD & 2 & 0.5 \\
\hline \multirow{18}{*}{$\begin{array}{l}\text { Faculty, } \\
\text { Institute, } \\
\text { and } \\
\text { Centre }\end{array}$} & Africa Regional Centre for Information Science & 8 & 2.0 \\
\hline & Agricultural and Forestry & 21 & 5.3 \\
\hline & Arts & 26 & 6.5 \\
\hline & Basic Medical Sciences & 14 & 3.5 \\
\hline & Centre for Entrepreneurship and Innovation & 3 & .8 \\
\hline & $\begin{array}{l}\text { Centre for Petroleum, Energy, Economics and } \\
\text { Law }\end{array}$ & 4 & 1.0 \\
\hline & Centre for Sustainable Development & 4 & 1.0 \\
\hline & Faculty of Education & 76 & 19.1 \\
\hline & Institute of African Studies & 4 & 1.0 \\
\hline & Institute of Child Health & 1 & .3 \\
\hline & Institute of Education & 2 & .5 \\
\hline & Law & 16 & 4.0 \\
\hline & Pharmacy & 9 & 2.3 \\
\hline & Public Health & 9 & 2.3 \\
\hline & Faculty of Science & 138 & 34.7 \\
\hline & Faculty of the Social Sciences & 43 & 10.8 \\
\hline & Faculty of Technology & 7 & 1.8 \\
\hline & Faculty of Veterinary Medicine & 13 & 3.3 \\
\hline
\end{tabular}

The result from Table 1 reveals that females make up $60.3 \%$ of the respondents with a frequency count of 240 , while $39.7 \%$ of the respondents were males with a frequency count of 158 . Majority of the respondents, with a frequency count of $216(54.3 \%)$, were within the age group of $25-29$ years, while the least proportion of the respondents, with a frequency count of $9(2.3 \%)$, were in the age group of 35-39 years. The result also revealed that $91.3 \%$ of the respondents were Masters' degree students, $5.5 \%$ were Ph.D. students, $2.8 \%$ were M.Phil/Ph.D. students and $0.5 \%$ were PGD students. 
The highest number of respondents was from the Faculty of Science with $34.7 \%$ (138) while the least faculty represented was the Institute of Child Health with $0.3 \%$ and a frequency count of 1.

\subsection{Answering the Research Questions}

Research Question 1: What is the level of ICT skills development among postgraduate students in the University of Ibadan?

The level of ICT Skills Development activities among postgraduate students in the University of Ibadan is presented in Table 2a. Table $2 b$ showed the distribution of ICT skills among the respondents.

Table 2a: ICT Skills Development Level of Respondents ( $\mathrm{N}=398$ )

\begin{tabular}{|l|l|l|}
\hline ICT Skills Development Level & Frequency & Percentage \\
\hline Poor & 6 & 1.5 \\
\hline Average & 56 & 14.1 \\
\hline Good & 144 & 36.2 \\
\hline Very good & 122 & 30.7 \\
\hline Excellent & 70 & 17.6 \\
\hline Total & 398 & 100.0 \\
\hline
\end{tabular}

Table 2a reveals that $144(36.2 \%)$ respondents rated their ICT skills development level as good, $122(30.7 \%)$ respondents rated it as very good, $70(17.6 \%)$ respondents rated it as excellent, $56(14.1 \%)$ respondents rated it as average and $6(1.5 \%)$ respondents rated it as poor.

Table 2b: ICT Skills among the Respondents ( $N=398$ )

\begin{tabular}{|l|l|l|}
\hline ICT Skills & No (\%) & Yes (\%) \\
\hline Web portal development & 78.9 & 21.1 \\
\hline Computer network design & 74.4 & 25.6 \\
\hline Application development & 73.9 & 26.1 \\
\hline Computer network security & 72.4 & 27.6 \\
\hline Computer programming & 69.3 & 30.7 \\
\hline Graphics design & 68.6 & 31.4 \\
\hline Blogging & 68.6 & 31.4 \\
\hline Database design and management & 64.1 & 35.9 \\
\hline Desktop publishing & 60.3 & 39.7 \\
\hline Online marketing & 58.3 & 41.7 \\
\hline Spreadsheets application & 43.7 & 56.3 \\
\hline Power Points design & 25.6 & 74.4 \\
\hline Word processing & 19.8 & 80.2 \\
\hline Operating computer & 19.1 & 80.9 \\
\hline
\end{tabular}


According to Table $2 \mathrm{~b}$, few respondents have ICT skills that can serve as means of employment (either as full time or part-time); such as web portal development (21.1\%), computer network design (25.6\%), application development (26.1\%), computer network security (27.6), computer programming (30.7), graphics design (31.4\%), and blogging (31.4\%). Majority of the respondents have skills in operating computer $(80.9 \%)$, word processing $(80.2 \%)$ and power points design $(74.4 \%)$ which are the basic skills they need for assignments and projects.

Research Question 2: What individual characteristics influence ICT skills development among postgraduate students in the University of Ibadan?

The influence of individual characteristics on ICT skills development among postgraduate students in the University of Ibadan is presented in Table 3.

Table 3: Chi-Square Test of Association between Individual Characteristics and ICT Skills Development $(\mathrm{N}=398)$

\begin{tabular}{|l|l|l|l|l|}
\hline $\begin{array}{l}\text { Individual } \\
\text { Characteristics }\end{array}$ & Pearson Chi-Square Value & DF & $\begin{array}{l}\text { Asymp. Sig. } \\
\text { (2 Sided) }\end{array}$ & Remarks \\
\hline Age & 11.092 & 8 & 0.197 & Not significant \\
\hline Educational level & 7.301 & 6 & 0.294 & Not significant \\
\hline Faculty of study & 43.155 & 34 & 0.135 & Not significant \\
\hline ICT competence level & 81.774 & 10 & $\mathbf{0 . 0 0 0}$ & Significant \\
\hline
\end{tabular}

The result indicates that there is no significant relationship between the age and ICT skills development $\left(X^{2} \mathrm{df}=8\right.$, $\mathrm{N}=398)=11.092, p>0.05)$; educational level and ICT skills development $\left(X^{2}(\mathrm{df}=6, \mathrm{~N}=398)=7.301, p>0.05\right)$; and faculty of study and ICT skills development $\left(X^{2}(d f=34, N=398)=43.155, p>=0.05\right)$ for the study respondents. However, there is a significant relationship between ICT competence level and ICT skills development $\left(X^{2}(\mathrm{df}=10\right.$, $\mathrm{N}=398)=81.774, \mathrm{p}<0.05)$.

Research Question 3: What social learning modelling conditions affect ICT skills development among postgraduate students in the University of Ibadan?

The influence of social learning modelling factors on ICT skills development among postgraduate students in the University of Ibadan is presented in Table 4.

Table 4: Spearman Rank Correlation Analysis of Social Learning Modelling Factors and ICT Skills Development ( $\mathrm{N}=398)$

\begin{tabular}{|l|l|r|}
\hline \multicolumn{2}{|l|}{} & ICT Skill Development \\
\hline \multirow{2}{*}{ Attention } & Correlation Coefficient & 0.148 \\
\cline { 2 - 3 } & Sig. (2-tailed) & $\mathbf{0 . 0 0 0}$ \\
\hline \multirow{2}{*}{ Retention } & Correlation Coefficient & 0.196 \\
\cline { 2 - 3 } & Sig. (2-tailed) & $\mathbf{0 . 0 0 0}$ \\
\hline \multirow{2}{*}{ Reproduction } & Correlation Coefficient & 0.247 \\
\cline { 2 - 3 } & Sig. (2-tailed) & $\mathbf{0 . 0 0 0}$ \\
\hline \multirow{2}{*}{ Motivation } & Correlation Coefficient & 0.213 \\
\cline { 2 - 3 } & Sig. (2-tailed) & $\mathbf{0 . 0 0 0}$ \\
\hline
\end{tabular}


Table 4 indicates a significant relationship between attention $(r=0.148, p<0.05)$; retention $(r=0.196, p<0.05)$, reproduction $(r=0.247, p<0.05$, ) and motivation $(r=0.213, p<0.05)$ and ICT skill development. Table 4 also indicates a positive but weak correlation between each of the social learning modelling factors and ICT Skills Development. Therefore, it can be deduced from the table that there is a positive but weak relationship between each of the social learning modelling factors and ICT skills development among postgraduate students in the University of Ibadan.

\subsection{Test of Hypotheses}

Hypothesis $\mathrm{H}_{01}$ : There is no significant relationship between individual characteristics and ICT skills development among postgraduate students in the University of Ibadan

The result of the test of hypothesis $\mathrm{H}_{01}$ is presented in Table 5 :

Table 5: ANOVA Table from the Regression Analysis for Hypothesis One

\begin{tabular}{|l|l|l|l|l|l|l|}
\hline Model & Sums Of Squares & DF & Mean Square & F & Sig. & Comments \\
\hline Regression & 19.491 & 5 & 3.898 & 11.678 & 0.000 & Significant \\
\hline Residual & 130.853 & 392 & 0.334 & & & \\
\hline Total & 150.344 & 397 & \multicolumn{5}{l|}{} \\
\hline $\mathrm{R}=0.360 ;$ Adjusted R Square $=0.119$
\end{tabular}

The dependent variable is ICT skill development

Table 5 shows the ANOVA table of the regression analysis that determined the influence of individual characteristics on the ICT skills development of postgraduate students. Table 5 reveals a significant relationship between individual characteristics and the ICT skills development of postgraduate students, that is, individual characteristics predict the ICT skills development of postgraduate students $\left(F_{(5,392)}=11.678, p<0.05\right)$.

Table 6: Coefficient Table for Hypothesis One

\begin{tabular}{|l|c|c|c|r|c|}
\hline \multirow{2}{*}{ Model } & \multicolumn{2}{|c|}{ Unstandardized Coefficients } & \multicolumn{1}{c|}{$\begin{array}{c}\text { Standardized } \\
\text { Coefficient (B) }\end{array}$} & T & Sig. \\
\cline { 2 - 6 } & \multicolumn{1}{|c|}{ B } & STD. ERROR & BETA & & \\
\hline Constant & 2.620 & 0.296 & & 8.838 & 0.000 \\
\hline Age & -0.096 & 0.035 & -0.137 & -2.736 & $\mathbf{0 . 0 0 7}$ \\
\hline Faculty of study & 0.001 & 0.004 & 0.017 & 0.017 & 0.719 \\
\hline Educational level & -0.140 & 0.062 & -0.111 & -2.261 & $\mathbf{0 . 0 2 4}$ \\
\hline ICT competence level & 0.144 & 0.029 & 0.235 & 4.930 & $\mathbf{0 . 0 0 0}$ \\
\hline
\end{tabular}

Table 6 presents information on the contribution and influence of individual characteristics towards ICT skills development among postgraduate students. It reveals that age $(\beta=-0.137, p<0.05)$, and educational level $(\beta=-$ $0.111, p<0.05)$ have significant influence on ICT skill development. It also reveals ICT competence level $(\beta=$ $0.235, p<0.05)$ as having positive significant influence on ICT skills development among postgraduate students. Only faculty of study $(\beta=0.017, p>0.05)$ has no significant influence on ICT skills development among postgraduate students. 
Hypothesis $\mathrm{H}_{02}$ : There is no significant influence of social learning modelling factors (attention, retention, reproduction, and motivation) on ICT skills development among postgraduate students in the University of Ibadan

Table 7: ANOVA Table from the Regression Analysis for Hypothesis Two

\begin{tabular}{|l|c|c|c|l|l|l|}
\hline Model & $\begin{array}{l}\text { Sums Of } \\
\text { Squares }\end{array}$ & DF & Mean Square & F & Sig. & Comments \\
\hline Regression & 11.701 & 4 & 2.925 & 8.292 & 0.000 & Significant \\
\hline Residual & 138.644 & 393 & 0.353 & & & \\
\hline Total & 150.344 & 397 & & & \\
\hline $\begin{array}{l}\text { R }=0.279 \\
\text { Adjusted R Square }=0.068\end{array}$
\end{tabular}

The dependent variable is ICT skill development

Table 7 shows the ANOVA table from the regression analysis that determined the influence of social learning modelling factors on the ICT skills development of postgraduate students. Table 8 reveals a significant relationship between social learning modelling factors on the ICT skills development of postgraduate students; that is, social learning modelling factors predict the ICT skills development of postgraduate students $\left(F_{(4,393)}=8.292, p<0.05\right)$.

Table 8: Coefficient Table for Hypothesis Two

\begin{tabular}{|c|c|c|c|c|c|}
\hline \multirow[t]{2}{*}{$\begin{array}{l}\text { Dependent Variable: Ict Skills } \\
\text { Development }\end{array}$} & \multicolumn{2}{|c|}{$\begin{array}{l}\text { Unstandardized } \\
\text { Coefficients }\end{array}$} & \multirow{2}{*}{$\begin{array}{c}\begin{array}{c}\text { Standardized } \\
\text { Coefficients }\end{array} \\
\text { BETA }\end{array}$} & \multirow[t]{2}{*}{$T$} & \multirow[t]{2}{*}{ Sig. } \\
\hline & B & STD. ERROR & & & \\
\hline \multicolumn{6}{|l|}{ Predictor Variables: } \\
\hline (Constant) & 1.769 & 0.101 & & 17.460 & 0.000 \\
\hline Attention & -0.015 & 0.029 & -0.031 & -0.513 & 0.609 \\
\hline Retention & 0.057 & 0.051 & 0.069 & 1.115 & 0.265 \\
\hline Reproduction & 0.281 & 0.101 & 0.165 & 2.785 & 0.006 \\
\hline Motivation & 0.127 & 0.056 & 0.129 & 2.277 & 0.023 \\
\hline
\end{tabular}

Table 8 presents information on the contribution, and influence of each social learning modelling factor on ICT skills development among postgraduate students. It shows that reproduction $(\beta=0.165, p<0.05)$ and motivation $(\beta=$ $0.129, p<0.05$ ) as having positive significant influence on ICT skills development among postgraduate students. It also reveals that both attention $(\beta=-0.031, p>0.05)$ and retention $(\beta=0.069, p>0.05)$ have no significant influence on ICT skills development among postgraduate students. 
Hypothesis $\mathrm{H}_{03}$ : There is no significant predictive joint effect of the independent variables (individual characteristics, and social learning modelling factors) on ICT skills development among postgraduate students in the University of Ibadan

Table 9: Regression/ANOVA Result for Hypothesis Three

\begin{tabular}{|l|l|l|l|l|l|l|}
\hline Model & $\begin{array}{l}\text { Sums Of } \\
\text { Squares }\end{array}$ & DF & Mean Square & F & Sig. & Comments \\
\hline Regression & 27.121 & 9 & 3.013 & 9.488 & 0.000 & Significant \\
\hline Residual & 123.223 & 388 & 0.318 & & & \\
\hline Total & 150.344 & 397 & \multicolumn{5}{l|}{} \\
\hline $\begin{array}{l}\mathrm{R}=0.425 \\
\text { Adjusted R. Square }=0.161\end{array}$
\end{tabular}

The dependent variable is ICT skills development

Table 9 reveals a significant influence of individual characteristics and social learning modelling factors on ICT skills development among postgraduate students in the University of Ibadan; $\left(F_{(9,388)}=9.488, p<0.05\right)$. Table 10 presented information on the contribution, and influence of individual characteristics and social learning modelling factors on ICT skills development among postgraduate students in the University of Ibadan.

Table 10: Coefficient Table for Hypothesis Three

\begin{tabular}{|c|c|c|c|c|c|}
\hline \multirow[t]{2}{*}{ Model } & \multicolumn{2}{|c|}{ Unstandardized Coefficients } & \multirow{2}{*}{\begin{tabular}{|c|}
$\begin{array}{c}\text { Standardized Coefficient } \\
\text { (B) }\end{array}$ \\
BETA \\
\end{tabular}} & \multirow[t]{2}{*}{$T$} & \multirow[t]{2}{*}{ Sig. } \\
\hline & B & STD. ERROR & & & \\
\hline Constant & 2.232 & 0.307 & & 7.270 & 0.000 \\
\hline \multicolumn{6}{|c|}{ Individual characteristics } \\
\hline Age & -0.075 & 0.035 & -0.107 & -2.166 & 0.031 \\
\hline Faculty of study & 0.005 & 0.004 & 0.004 & -0.015 & 0.988 \\
\hline Educational level & -0.135 & 0.062 & -0.107 & -2.223 & 0.027 \\
\hline ICT competence level & 0.127 & 0.029 & 0.208 & 4.387 & 0.000 \\
\hline \multicolumn{6}{|c|}{ Social learning modelling factors } \\
\hline Attention & -0.007 & 0.028 & -0.014 & -0.243 & 0.808 \\
\hline Retention & 0.027 & 0.047 & 0.033 & 0.554 & 0.580 \\
\hline Reproduction & 0.227 & 0.098 & 0.133 & 2.317 & 0.021 \\
\hline Motivation & 0.119 & 0.053 & 0.121 & 2.247 & 0.025 \\
\hline
\end{tabular}

According to Table 10, out of the four sub-variables in individual characteristics, only Faculty of study has no significant influence on ICT skills development among postgraduate students $(\beta=0.004, p>0.05)$. Other subvariables have significant influence on ICT skills development among postgraduate students in the University of Ibadan; these are: age $=(\beta=-0.107, p<0.05)$, educational level $=(\beta=-0.107, p<0.05)$, and ICT competence level $=(\beta=0.208, p<0.05)$. For the sub-variables under social learning modelling factors, only two out of the four sub-constructs have significant influence on ICT skills development among postgraduate students of the University of Ibadan. 
Attention $=(\beta=-0.014, p>0.05)$, and retention $=(\beta=0.033, p>0.05)$ have no significant influence on ICT skill development, while reproduction ( $\beta=0.133, p=0.021)$, and motivation $=(\beta=0.121, p=0.025)$ have significant influence on ICT skills development. This result of the test of hypothesis 3 led to the research model (Figure 1).

Individual Characteristics

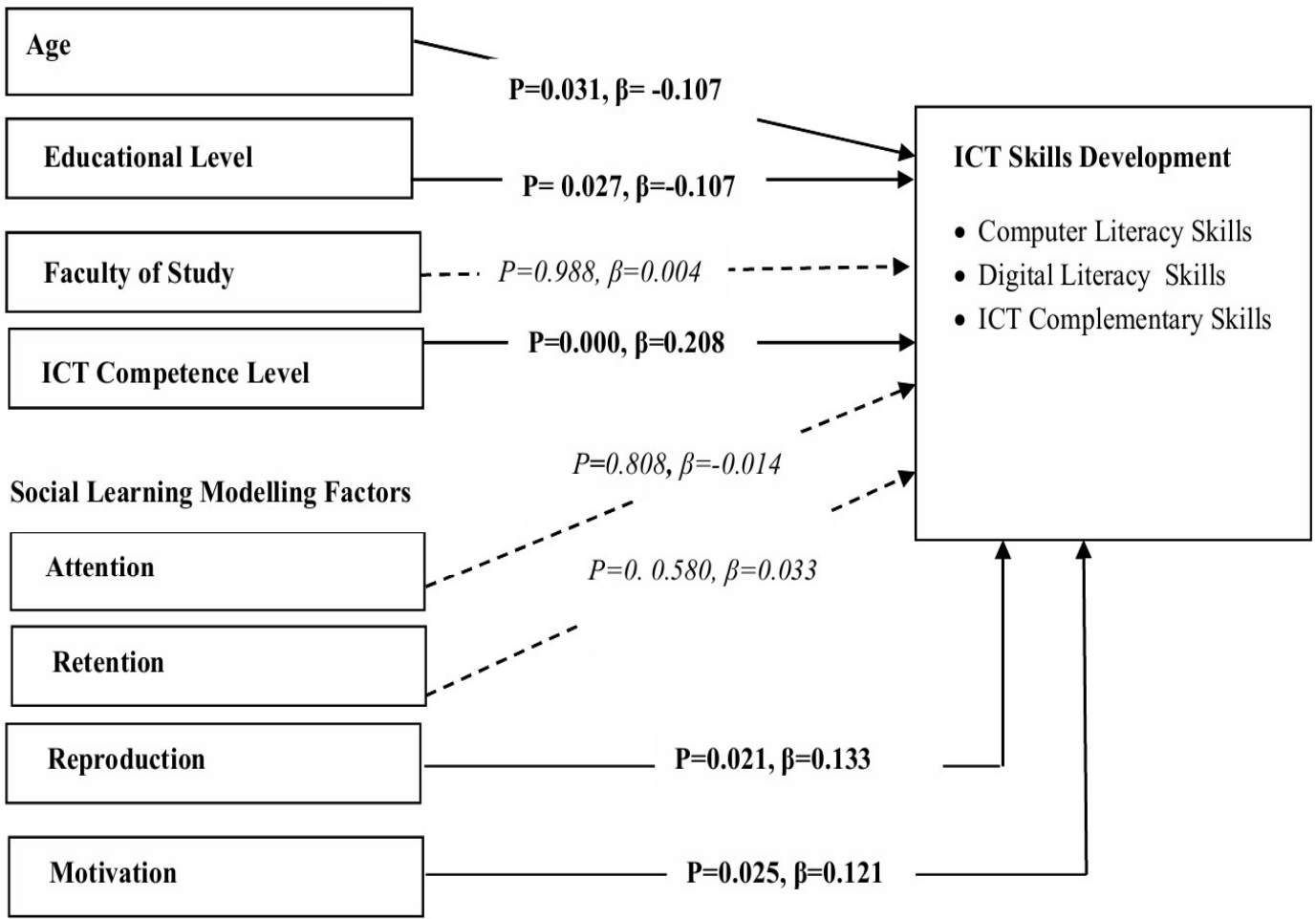

Significant relationship

Non-significant relationship

Figure 1: Research Model 


\section{DISCUSSION OF FINDINGS}

Majority of the respondents rated their level of ICT development as good; this is supported by the study by Poelmans, Truyen, and Stockman (2012) showing that students in higher education rated their ICT skills as high. The study showed that there is a significant relationship between ICT competence level and ICT skills development. ICT competence level was one of the factors which positively influence postgraduate students' ICT skills development. This finding agrees with Mwewa, Elizabeth and Allan (2012) who found out that students' confidence in the use of ICT equipment affected their ICT skills development positively. The study reveals that age and educational level have a negative significant influence on ICT skill development. This finding agrees with Mwewa, Elizabeth and Allan (2012) who revealed that age and year of study of the students affected negatively their ICT skills development. This implies that the higher their ages, and educational level, the lower their ICT skill development. Therefore, it can be said that younger students are more developed in terms of ICT skills.

The findings reveal that faculty of study has no significant influence on ICT skills development among postgraduate students. This implies that it cannot be said that postgraduate students from certain faculties of study have more developed ICT skill than others. This is because ICT has permeated every field of study and has become a useful research tool for postgraduate studies; therefore, postgraduate students acquire ICT skills irrespective of their faculties of study. ICT skills have been known to improve students' employability. The relationship between ICT skills development and social learning modelling factors (attention, retention, reproduction, and motivation) were found to be weak and positive. Findings from the study reveal that individual characteristics have a significant influence on ICT skill development. The regression model statistically significantly predicts the outcome variable ICT skills development of postgraduates in the University of Ibadan.

\section{CONCLUDING REMARKS}

This study applied Albert Banduras' (1977) social learning theory, as well as individual characteristics to investigate factors influencing ICT skills development among postgraduate students in the University of Ibadan. The result of the frequency count and percentages showed that the majority of the postgraduate students rated their ICT skills development level to be good. Findings from the test of hypotheses using the chi-square test of association revealed that for individual characteristics, only ICT competence level has a significant relationship with ICT skills development while age, educational level and faculty of study do not. Findings also from the test of hypothesis using Spearman rank correlation reveal that social learning modelling factors (attention, retention, reproduction, motivation) have a statistical relationship with ICT skill development.

The result of the regression coefficient analysis when all the eight sub-constructs of the independent variables were regressed against the dependent variable; age, educational level, ICT competence level, reproduction, and motivation have a significant influence on ICT skill development, while faculty of study, attention, retention did not. The findings from the test of hypothesis using multiple regression analysis revealed that there is a significant influence between the independent variables (individual characteristics and social learning modelling conditions) and the ICT skills development among postgraduate students of the University of Ibadan. The study concludes that individual characteristics and social learning modelling conditions do have a significant influence on ICT skills development among postgraduate students. The study also shows that students know that ICT skills are required to succeed in today's world and that they are deemed necessary for employment. 


\section{CONTRIBUTIONS TO KNOWLEDGE}

This study used Albert Banduras' (1977) social learning theory which was previously used in the social sciences but rarely used in the field of ICT for development. In light of the literature review and the results of the study based on the influence of individual characteristics and social learning modelling conditions on ICT skill development, the following recommendations are made:

- ICT skills development should be incorporated into the academic programme of postgraduate students as part of their curriculum, and staff should be trained on how to effectively teach the courses to the students.

- teamwork and collaboration among peers should be encouraged to stimulate interest in ICT skills development.

- the institution should provide ICT training rooms and well equipped computer laboratories for students. ICT software packages should be made more accessible and cheaper to learn by interested individuals.

- educational institutions and the government should implement effective policies for students to acquire sufficient ICT skills.

- the government and non-governmental organisation should sponsor training programmes as well as support ICT certification examinations targeted at fostering the acquisition of ICT skills.

\section{Endnotes/Acknowledgements}

A version of this paper was presented at the 24th iSTEAMS International Multidisciplinary Conference, Accra, Ghana, June 2-6, 2020. We appreciate the reviewers and the conference audience whose comments have helped to improve the quality of the paper for journal Publication.

\section{REFERENCES}

1. Adesote, S. A. \& Fatoki, O. R. (2013). The role of ICT in the teaching and learning of history in 21 st century. Educational Research Review, 8 (21), 2155 - 2159.

2. Adomi, E. E. \& Kpangban, E. (2010). Application of ICTs in Nigerian Secondary Schools. Library Philosophy and Practice (e-journal). 345

3. Agbetuyi, P. A. \& Oluwatayo, J. A. (2012). ICT in Nigerian educational system. Mediterranean Journal of Social Sciences, 3(3), 41. DOI: 10.5901/mjss.2012

4. Agbodike C. F., Igbokwe-lbeto C. J., \& Umeifekem, U. (2015). Youth unemployment and labour productivity in Nigeria: The nexus. Journal of Research and Development, 2(8), 22.

5. Alade I. A. \& Ogunsola, K. (2008) Impact of the Access to Information Technology-Mediated Potentials (IT-MP) on the Socio-Educational Practices of Nigeria Citizens. Conference proceedings, at the Fifth PanCommonwealth Forum on Open Learning, London, July 13-17, 2008

6. Asgarkhani, M. \& Wan J. (2008). A pilot study of current trends in information and communication technology (ICT) education within the tertiary sector. Contemporary Management Research, 4(4), 291 304.

7. Bandura, A. (1977). Social Learning Theory. Englewood Cliffs, NJ: Prentice Hall.

8. Barakabitze, A. A., Kitindi, E. J., Sanga, C., Kibirige, G. \& Makwinya, N. (2015). Exploring students' skills and attitudes on effective use of ICTs: Case study of selected Tanzanian public secondary schools. Universal Journal of Educational Research, 3(6), 407-425, DOI: 10.13189/ujer.2015.030609 
9. Bassey, B. C. \& Ushie, A. M. (2013). The role of ICT in skilled manpower development through vocational technical education among higher institutions in Cross River State, Nigeria. International Journal of Vocational and Technical Education. 5(5), 92-99. DOI:10.5897/IJVTE2013.0132. Retrieved on 19 July 2018 from http://www.academicjournals.org/IJVTE

10. Centeno, C., Cullen, J., Kluzer, S., \& Hache, A. (2012). Information and Communication Technologies (ICTs) for Disadvantaged Youth: Opportunities and Challenges. Luxembourg: Publications Office of the European Union.

11. De-Hoyos, M., Green A. E., Barnes S. A., Behle H., Baldauf B., \& Owen D. (2012). Literature Review on Employability. Institute for Prospective Technological Studies, Joint Research Centre, European Commission. $\quad$ Retrieved on 19 July 2019 from https://publications.jrc.ec.europa.eu/repository/bitstream/JRC78601/jrc78601.pdf

12. Economic Commission for Africa (ECA) (2008). Africa Regional Meeting for Sustainable Development. Retrieved 10 October 2019 from https://www.uneca.org/sites/default/files/uploadeddocuments/SDG/africa_regional_report_on_the_sustainable_development_goals_summary_english_rev .pdf

13. Elsaadani, M. (2015). Information and communication technology skills' sufficiency of Egyptian accounting graduates. International Journal of Advanced Information Technology), 5(12).

14. European Commission (2008). Digital Literacy. European Commission Working Paper and Recommendations from Digital Literacy High-Level Expert Group. Retrieved on 23 April 2020 from https://www.ifap.ru/library/book386.pdf

15. Eurostat (2020). Youth Unemployment. Retrieved on 2 June 2020 from https://ec.europa.eu/eurostat/statistics-explained/index.php/Youth_unemployment

16. Eze, U. F. (2013). Integrating ICT in re-branding Nigerian youths for constructive empowerment and mental reengineering. Journal of Business and Management. 11(2).

17. Gay, L. R. \& Airasian, P. (2003). Educational Research: Competencies for Analysis and Applications, 7th ed., Pearson Education, Inc, Upper Saddle River, New Jersey. Retrieved on 20 April 2019 from http://englishlangkan.com/produk/E\%20Book\%20Educational\%20Research\%20L\%20R\%20Gay\%20Pea rson\%202012.pdf

18. Gupta, V. \& Ansari, M. A. (2007). Impact of technology on societal development and e-governance. Electronic Journal of Academic and Special Librarianship, 8(1).

19. Hall, M., Nix, I. \& Baker, K. (2013). Student experiences and perceptions of digital literacy skills development: engaging learners by design? Electronic Journal of e-Learning 11(3). Retrieved on 23 April 2020 from www.ejel.org

20. Hou, Y. (2015). An investigation of social factors in children's foreign language learning - a case study of Taiwanese elementary school students. Open Journal of Modern Linguistics. 5, 105-119. Retrieved on 6 September 2019 from http://www.scirp.org/journal/ojml

21. International Telecommunication Union. (2014). Digital opportunities: Innovative ICT solutions for youth employment Report. Retrieved on 6 September 2019 from https://www.itu.int/en//TU-D/DigitalInclusion/Youth-and-Children.

22. Israel, O. \& Ediseri, E. (2014). ICT skills and internet usage of undergraduates of library and information science departments of Delta and Edo States' universities. International Journal of Library and Information Science. 6(5), 98-107. DOI: 10.5897/IJLIS2013.0360 http://www.academicjournals.org/IJLIS

23. Jagodic, G. \& Dermol, V. (2015). ICT Tools for the Development of Entrepreneurial Competencies. Joint International Conference. 27-29 May, 2015. Bari, Italy. Retrieved on 12 December 2017 from https://ideas.repec.org/h/tkp/mklp15/2123-2129.html 
24. Lallana, E. C. \& Margaret, U. Y. (2003). The Information Age. Retrieved on July 152018 from http://www.eprimers.org

25. McLeod, S. A. (2016). Nature Nurture in Psychology. Retrieved on 12 April 2020 from https://www.simplypsychology.org/bandura.html

26. Mwewa, P., Elizabeth, S. \& Allan, M. (2012). An investigation into the development of ICT skills among mathematics students in higher learning institutions: A case of Mukuba University. International Journal of Science and Research. 3. 257

27. Ogunsola K. \& Adekola A. (2019). Institutional Factors Influencing Internet Use among Postgraduate Students in Selected Universities in South-western Nigeria. African Journal of Theory and Practice of Educational Research, 6(1), 131-141

28. Ogunsola, K. \& Alade, I.A. (2016). Assessment of E-Learning Facilities and Their Utilization in Curriculum Delivery of Colleges of Education Programmes in Lagos State, Nigeria. African Journal of Theory and Practice of Educational Assessment, 4, 64-77

29. Partnership for 21st Century Skills (2009). A Framework for 21st Century Learning. Available at: www.21stcenturyskills.org.

30. Poelmans, S., Truyen, F. \& Stockman, C. (2012). ICT Skills and Computer Self-Efficacy of Higher Education Students. Proceedings of International Technology Education and Development Conference. 5th-7th March 2012, Valencia, Spain. ISBN: 978-84-615-5563-5

31. SearchCIO (2016). ICT: Information and Communications Technology - or Technologies. Retrieved on 12 April 2019 from http://searchcio.techtarget.com/definition/ICT-information-and-communicationstechnology-or-technologies

32. Statista (2020). Youth Unemployment Rate in Nigeria in 2019. Retrieved on 2 June 2020 from https://www.statista.com/statistics/812300/youth-unemployment-rate-in-nigeria/

33. World Bank Live (2016). Information and Communications Technologies for Development. Retrieved on 12 April 2019 from http://live.worldbank.org/information-communications-technology-development

34. Yigitcanlar, T. \& Baum, S. (2009). Providing Youths with Skills, Training and Employment Opportunities through ICT Initiatives. In: Public-Private Partnerships and ICTs. ICFAI University Press. http://eprints.qut.edu.au/ 